\title{
Alternative co-digestion scenarios for efficient fixed-dome reactor biomethanation processes
}

Fotidis, loannis; Laranjeiro, Tiago; Angelidaki, Irini

Published in:

Journal of Cleaner Production

Link to article, DOI:

10.1016/j.jclepro.2016.04.008

Publication date:

2016

Document Version

Peer reviewed version

Link back to DTU Orbit

Citation (APA):

Fotidis, I., Laranjeiro, T., \& Angelidaki, I. (2016). Alternative co-digestion scenarios for efficient fixed-dome reactor biomethanation processes. Journal of Cleaner Production, 127, 610-617.

https://doi.org/10.1016/j.jclepro.2016.04.008

\section{General rights}

Copyright and moral rights for the publications made accessible in the public portal are retained by the authors and/or other copyright owners and it is a condition of accessing publications that users recognise and abide by the legal requirements associated with these rights.

- Users may download and print one copy of any publication from the public portal for the purpose of private study or research.

- You may not further distribute the material or use it for any profit-making activity or commercial gain

- You may freely distribute the URL identifying the publication in the public portal

If you believe that this document breaches copyright please contact us providing details, and we will remove access to the work immediately and investigate your claim. 


\section{Accepted Manuscript}

Alternative co-digestion scenarios for efficient fixed-dome reactor biomethanation processes

Ioannis A. Fotidis, Tiago Filipe Vicente Costa Laranjeiro, Irini Angelidaki

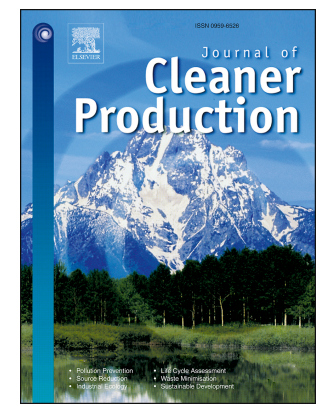

PII:

S0959-6526(16)30250-5

DOI:

10.1016/j.jclepro.2016.04.008

Reference: JCLP 7014

To appear in: Journal of Cleaner Production

Received Date: 15 December 2015

Revised Date: 8 February 2016

Accepted Date: 1 April 2016

Please cite this article as: Fotidis IA, Laranjeiro TFVC, Angelidaki I, Alternative co-digestion scenarios for efficient fixed-dome reactor biomethanation processes, Journal of Cleaner Production (2016), doi: 10.1016/j.jclepro.2016.04.008.

This is a PDF file of an unedited manuscript that has been accepted for publication. As a service to our customers we are providing this early version of the manuscript. The manuscript will undergo copyediting, typesetting, and review of the resulting proof before it is published in its final form. Please note that during the production process errors may be discovered which could affect the content, and all legal disclaimers that apply to the journal pertain. 


\section{Alternative co-digestion scenarios for efficient fixed-dome reactor}

\section{biomethanation processes}

Ioannis A. Fotidis*, Tiago Filipe Vicente Costa Laranjeiro and Irini Angelidaki

Department of Environmental Engineering, Technical University of Denmark, DK-2800 Kgs. Lyngby, Denmark.

*Corresponding Author: Ioannis A. Fotidis, Department of Environmental Engineering, Technical University of Denmark, DK-2800 Kgs. Lyngby, Denmark, Phone: (+45) 45251418; Fax: (+45) 45933850; e-mail: ioanf@env.dtu.dk 


\begin{abstract}
Many of the existing low-tech biogas reactors in the remote rural areas of developing countries have been abandoned due to the lack of substrates. This study investigated if unutilized biomasses are able to support an efficient biomethanation process with low carbon footprint, in these rural areas where low-tech reactors have been abandoned. Thus, the aims of this study were: a) to identify and evaluate alternative biomasses as anaerobic digestion substrates at a remote rural area site in India; b) to propose an efficient continuous biomethanation scenario for low-tech reactors; c) to assess the influence of the operational parameters on the stability of the anaerobic digestion process. The highest methane yield (137-159 $\mathrm{NmL} \mathrm{CH}_{4} \mathrm{~L}^{-1}$ ) and codigestion synergy (>20\% more $\mathrm{CH}_{4}$ than expected), were achieved by co-digestion of wastewater, cow manure, banana and rice by-products at 79.3/4.2/16.3/0.2 $\mathrm{ww}^{-1} \mathrm{VS}$ ratio, respectively. Three fixed-dome reactors, $\mathrm{R}_{30}, \mathrm{R}_{45}$ and $\mathrm{R}_{60}$, fed with all substrates, operated with hydraulic retention times of 30,45 , and 60 days and organic loading rates of $2.18,1.46$, and $1.09 \mathrm{~g} \mathrm{VS} \mathrm{L}^{-1} \mathrm{~d}^{-1}$, respectively (different co-digestion scenarios). $\mathrm{R}_{60}$ was the best continuous co-digestion scenario with $45 \%$ and $13 \%$ higher energy recovery from biomasses' utilization and $69 \%$ and $25 \%$ less greenhouse gas (GHG) emissions, compared to $\mathrm{R}_{30}$ and $\mathrm{R}_{45}$, respectively. These results indicate that is possible to operate efficiently low-tech biogas reactors with utilized biomasses as anaerobic digestion substrates.
\end{abstract}

Keywords: Anaerobic digestion; Banana plant; BMP; Low-tech reactor; Rice husk; Rice straw. 


\section{Introduction}

Emerging economies (e.g. China and India) are becoming major players in energy consumption, with increasing imports of oil and coal (IEA, 2013). Nevertheless, approximately $24 \%$ of the population in developing countries does not have access to electricity, and $49 \%$ still relies on traditional uses of biomass to cover their basic energy needs such as heating and cooking (IEA, 2011). Most of these people are located in rural areas (Cozzi, 2011). It is estimated that $80 \%$ of the total energy consumed in rural areas of India comes from sources such as livestock dung, firewood and crop byproducts (Rao et al., 2010). This low energy availability in the rural areas of developing countries is triggering the quest for indigenous, accessible and renewable energy sources. Biomass-related technologies have attracted interest due to the relatively low production cost and low environmental impacts associated with them as well as due to the abundance and availability of substrates needed to produce them (Purohit, 2009). In addition, these technologies could be combined with sanitation development and reduction of greenhouse gas (GHG) emissions, which are additional worrisome issues in these areas (Dedinec et al., 2015).

Anaerobic digestion (AD) process could be a good candidate to fulfill the basic domestic energy needs of the inhabitants in these remote areas without the negative implications of the conventional biomass-related technologies (e.g. GHG and other emissions). $\mathrm{AD}$ is a microbially catalyzed process that allows the valorization of organic waste by the production of a high-energy content gas (biogas) and a liquid by-product (digestate) with high fertilizing value (Alburquerque et al., 2012; Roubík et al., 2016).

Biogas based, clean cooking systems are becoming more popular in Asian rural areas (Banerjee et al., 2016). Experience from previous projects in rural areas has shown 
that when biogas was produced in low-tech reactors (e.g. fixed-dome, floating cover and balloon or tube digester), could successfully be collected and used for cooking and lighting; eliminating the need for other energy sources (e.g. firewood, dried manure, etc.) (Bond and Templeton, 2011). The low-tech biogas reactors used in developing countries, have different configurations but are often compact, underground structures, typically with an inlet mixing chamber, an expansion chamber or outlet tank, and a gas collection exit on the top. Furthermore, they often don't incorporate mixing or heating systems and have limited handling requirements (Tilley et al., 2014). Fixed-dome reactors are the most cost-effective type among all the small capacity reactors $\left(1-6 \mathrm{~m}^{3}\right.$ working volume), based on the installation cost, the operational cost and the payback period (Singh and Sooch, 2004).

According to Cheng et al. (2014), the technical weaknesses and consecutively the inefficient operation for small capacity reactors, derives from: the structural components, the biogas utilization equipment, the biogas distribution systems, the digestate disposal, the operators' training and the biogas production. These six problems have been assessed by many researchers (e.g. (Chang et al., 2011; Jha et al., 2012; Sovacool et al., 2015; Suzuki, 2015; Thien Thu et al., 2012)) and practical solutions have been proposed. However, even though these technical issues can be solved, there are still many cases where the users abandoned their reactors due to the absence of available biomasses (Mwirigi et al., 2014; Pérez et al., 2014). Specifically, it has been reported that the basic operational problem of low-tech reactors is the availability and/or seasonality of the substrates (Ullah et al., 2015). Furthermore, in these close, remote societies, almost every available biomass resource is being exploited to the maximum extent, which makes it difficult to find substrates that will be provided willingly by the 
inhabitants. Thus, because conventional co-substrates are scarce, and since usage of energy crops is not an option, alternative co-substrates for manure-based biogas production, need to be identified.

Organic agricultural by-products of these rural areas could provide the solution to this problem. A good example of an unused by-product is the rice husk (a by-product of the rice milling process), which is mainly disposed in the developing countries through dumping in open fields followed by burning (Pode, 2016). This process contributes significantly to GHG emissions, reduces the productivity of the nearby lands, and causes air pollution from smoke and particulate matter emissions. The results of this disposal method are posing a direct health risk to people living near the dumpsites with potential skin, nose and eye irritation, decreased lung function and lung disease as asbestos-like silica fibers are released in the process (Bohra et al., 2013). The potential use of these types of by-products as substrates in low-tech biogas reactors could limit the problems that conventional disposal methods cause. Another important aspect especially relevant for the low-tech reactors, is the uncontrolled methane emissions from the outlet storage of the digestate (residual methane potential), that could generate high GHG emissions (Seppälä et al., 2013).

Today, there are more than 3.7 million biogas plants in India (Rao et al., 2010) and many of these are located in remote rural areas and have been abandoned due to the absence of the necessary amounts of substrate. Therefore, the objective of the current study was to investigate if in the remote rural areas, where low-tech reactors have been shut down, there are the available organic by-products able to support an efficient AD process with low carbon footprint. Therefore, Jyot Sujan, a small village with 1800 inhabitants composing 250 households, located in West Bengal jungle (India) with no 
access to domestic electricity, was chosen as a representative case study site of these remote areas. The village has eight fixed-dome reactors constructed in 2003 by the local government. All the reactors have been abundant for more than five years because their users claim lack of available substrates (Fig. S1, supplementary material). Notably, all cooking energy requirements at the study site are met today by burning dried cow dung.

Based on the above, three aims were addressed in the current research. First, to identify available substrates in this remote rural area site and determine their mono- and co- digestion biological methane potentials (BMP). Second, to assess the continuous utilization of the available substrates in lab-scale, fixed-dome reactors. Third, to evaluate the influence of the operational parameters on methane production and residual methane potential of the digestate.

\section{Materials and methods}

The BMP of the mono and co-digested substrates were assessed through two experimental series, denoted "BMP assay-I" for mono-substrates, and "BMP assay-II" for co-digested substrates. Subsequently, the most promising co-digestion mixture was used in mesophilic $\left(37 \pm 1^{\circ} \mathrm{C}\right)$ fixed-dome continuous reactor experimental series testing three co-digestion scenarios. Finally, the maximum residual methane potential was determined for each one of the three fixed-dome reactors.

\subsection{Inocula}

Two different thermophilic $\left(53 \pm 1^{\circ} \mathrm{C}\right)$ methanogenic inocula derived from Snertinge centralized biogas plant (Denmark) were used in BMP assays-I and -II. The inocula were placed in an incubator for seven days to degas prior to use. The three fixed-dome reactors were inoculated with mesophilic $\left(37 \pm 1^{\circ} \mathrm{C}\right)$ inoculum derived from Hashøj 
biogas plant, Denmark. The basic characteristics of the inocula used in the BMP and fixed dome reactor assays are presented in Table 1.

Table 1. Characteristics of the inocula used in the BMP and the fixed-dome continuous reactor experiments $(n=3, S D)$

\begin{tabular}{|c|c|c|c|}
\hline \multirow[t]{2}{*}{ Parameters } & \multicolumn{3}{|l|}{ Inocula } \\
\hline & BMP assay-I & BMP assay-II & Fixed dome reactors \\
\hline Temperature $\left({ }^{\circ} \mathrm{C}\right)$ & $53 \pm 1$ & $53 \pm 1$ & $37 \pm 1$ \\
\hline $\mathrm{pH}$ & 8.79 & 8.32 & 7.88 \\
\hline $\mathrm{TS}^{\mathrm{a}}\left(\mathrm{g} \mathrm{L}^{-1}\right)$ & $11.22 \pm 0.39$ & $20.37 \pm 1.04$ & $42.33 \pm 0.58$ \\
\hline $\mathrm{VS}^{\mathrm{b}}\left(\mathrm{g} \mathrm{L}^{-1}\right)$ & $5.61 \pm 0.33$ & $12.19 \pm 0.13$ & $28.82 \pm 0.23$ \\
\hline $\mathrm{TKN}^{\mathrm{c}}\left(\mathrm{g} \mathrm{N} \mathrm{L}^{-1}\right)$ & $1.21 \pm 0.02$ & $1.75 \pm 0.05$ & $4.04 \pm 0.22$ \\
\hline Ammonia $\left(\mathrm{g} \mathrm{NH}_{4}{ }^{+}-\mathrm{N} \cdot \mathrm{L}^{-1}\right)$ & $0.90 \pm 0.06$ & $1.27 \pm 0.03$ & $3.18 \pm 0.16$ \\
\hline $\operatorname{VFA}^{d}\left(g^{-1}\right)$ & $0.24 \pm 0.05$ & $0.18 \pm 0.02$ & $1.20 \pm 0.15$ \\
\hline
\end{tabular}

${ }^{\mathrm{a}}$ Total solids, ${ }^{\mathrm{b}}$ Volatile solids, ${ }^{\mathrm{c}}$ Total Kjeldahl nitrogen, ${ }^{\mathrm{d}}$ Volatile fatty acids

\subsection{Substrates}

Four different available AD substrates were identified in the study site.

Specifically, wastewater (WW) with average production of $2735 \mathrm{~m}^{3} \mathrm{y}^{-1}$; cow manure $(\mathrm{CM})$ with an estimated total production of 233 tons $\mathrm{DM} \mathrm{y}^{-1}$; banana and rice plantations with 6 and 175 tons $\mathrm{DM} \mathrm{y}^{-1}$ of biomass, respectively. For experimentation purposes, banana and rice residual biomasses were divided in three (banana lower (BSLo), middle (BS-Mid) and upper (BS-Up) parts) and two (rice husk (RHu) and straw (RSt)) distinct fractions, respectively. The total solids (TS) or dry matter (DM) and 
volatile solids (VS) content of the organic agricultural by-products used in this work are presented in Table 2. Samples of each substrate were collected from the site, taken to the laboratory in Denmark, where the large plant parts were cut down with a pair of scissors to small pieces $(5-10 \mathrm{~mm})$ and stored to $-18^{\circ} \mathrm{C}$ until used.

Table 2. Substrate characteristics in terms of TS or DM and VS content

\begin{tabular}{|c|c|c|}
\hline & TS or DM & $\mathrm{VS}$ \\
\hline Wastewater $\left(\mathrm{WW}, \mathrm{g} \mathrm{L}^{-1}\right)$ & $116.10 \pm 1.12$ & $51.22 \pm 3.81$ \\
\hline Cow manure $\left(\mathrm{CM}, \mathrm{g} \mathrm{L}^{-1}\right)$ & $191.03 \pm 4.36$ & $150.24 \pm 1.46$ \\
\hline Rice straw (RSt, $\mathrm{g} \mathrm{kg}^{-1}$ ) & $844.23 \pm 0.14$ & $678.33 \pm 0.13$ \\
\hline Rice husk (RHu, $\mathrm{g} \mathrm{kg}^{-1}$ ) & $900.82 \pm 0.33$ & $748.44 \pm 0.04$ \\
\hline Banana stem-Lower part (BS-Lo, $\mathrm{g} \mathrm{kg}^{-1}$ ) & $36.64 \pm 0.69$ & $26.92 \pm 0.47$ \\
\hline Banana stem-Middle part (BS-Mid, $\mathrm{g} \mathrm{kg}^{-1}$ ) & $45.48 \pm 5.12$ & $35.35 \pm 5.11$ \\
\hline Banana stem-Upper part (BS-Up, $\mathrm{g} \mathrm{kg}^{-1}$ ) & $44.21 \pm 3.35$ & $34.40 \pm 3.9$ \\
\hline
\end{tabular}

\subsection{Experimental setup of BMP assays-I and -II}

Both biomethanation potential experiments for mono-substrates (BMP assay-I) and co-substrates (BMP assay-II) were performed according to the method described by Angelidaki et al. (2009). BMP assay-I performed in glass shield vessels with 100 and $320 \mathrm{~mL}$ of working and total volume, respectively. Three concentrations of the monosubstrates were tested $\left(2,4\right.$ and $\left.8 \mathrm{~g} \mathrm{VS} \mathrm{L}^{-1}\right)$ to avoid potential overload or inhibition of the used inoculum with the exception of WW where only $10.2 \mathrm{~g} \mathrm{VS} \mathrm{L}^{-1}$ was tested. After the introduction of the substrates, $80 \mathrm{~mL}$ of inoculum and deionized water (when needed) were added to obtain the $220 \mathrm{~mL}$ headspace in the batch reactors. BMP assay-II 
performed in glass shield vessels with 118 and $40 \mathrm{~mL}$ of working and total volume, respectively. The working volume of its batch reactor was consisted of $32 \mathrm{~mL}$ of inoculum and $8 \mathrm{~mL}$ of co-substrates and water (if needed). Two different co-digestion combinations (6M and $12 \mathrm{M}$ substrate utilization scenarios, respectively) were tested in Batch assay-II, to determine the best combination of substrates. Specifically, the concentrations of each substrate in these combinations were based on the reported generation of biomasses in the study site, distributed in $12(12 \mathrm{M})$ and $6(6 \mathrm{M})$ months of substrate utilization and co-digested with WW+CM mixture $\left(19 / 1 \mathrm{ww}^{-1}\right)$. Additionally, the $6 \mathrm{M}$ and $12 \mathrm{M}$ combinations were tested for co-digestion of all available substrates. The organic loading of the different tested co-digestion scenarios in the BMP assay-II are depicted in Table S1 (supplementary material).

Blanks were prepared with inoculum added water instead of substrate, in order to estimate the background methane production from the inoculum, in both BMP assays. Furthermore, batch reactors with cellulose as substrate (Avicel® PH-101, Sigma Aldrich) were used $\left(2 \mathrm{~g} \mathrm{~L}^{-1}\right)$ as control substrate to validate the two BMP assays. The BMP value of Avicel in BMP assays-I and -II was between 92 and 97\% of the theoretical value (415 $\mathrm{NmL} \mathrm{CH}_{4} \mathrm{~g}^{-1} \mathrm{VS}$ ), which supports the validity of the BMP assays. All the batch bottles were flushed with $\mathrm{N}_{2} / \mathrm{CO}_{2}\left(80 / 20 \% \mathrm{vv}^{-1}\right)$, closed with thick butyl rubber stoppers and an aluminum cap and inoculated under thermophilic conditions $\left(55^{\circ} \mathrm{C}\right)$. All experiments performed in triplicates $(n=3)$ to test the homogeneity of the substrates and reproducibility of the results.

\subsection{Experimental setup of the fixed-dome reactors}

In order to assess the most realistic co-digestion scenario identified in BMP assayII, three identical lab-scale, fixed dome continuous reactors were designed and 
constructed based on the typical Chinese fixed-dome model (Pérez et al., 2014). The three reactors, $R_{30}, R_{45}$ and $R_{60}$, were operated with HRTs of 30,45 , and 60 days and OLRs of 2.18, 1.46, and $1.09 \mathrm{~g} \mathrm{VS} \mathrm{L}^{-1} \mathrm{~d}^{-1}$, respectively (different co-digestion scenarios). The total and the working volume of each reactor was 2.3 and $2 \mathrm{~L}$, respectively, with liquid and gas sampling ports as seen in Fig. S2 (supplementary material). Each reactor's setup was consisted of a funnel as the inlet tank, connected to the reactor through a metal tube. Additionally, the outlet tank consisted of an open glass bottle, with an exit for the digestate. A gasbag connected to the reactor dome with a tube was used to collect the produced biogas. The volume of the biogas was measured with a water-displacement gas meter. The reactors placed in a mesophilic $\left(37 \pm 1^{\circ} \mathrm{C}\right)$ incubator and feed once per day with the co-digestion feedstock (Table 3).

Table 3. The feedstock composition used in the fixed-dome reactors. Yearly produced quantities derived from the remote rural area, proportionally introduced in the feedstock

\begin{tabular}{ll}
\hline Biomasses & Feedstock content $\left(\mathrm{g} \mathrm{VS} \mathrm{L}^{-1}\right)$ \\
\hline Wastewater + Cow manure (WW+CM) & $54.72 \pm 0.03$ \\
Rice straw (RSt) & $5.21 \pm 0.07$ \\
Rice husk (RHu) & $5.49 \pm 0.06$ \\
Banana stem-Low part (BS-Lo) & $0.03 \pm 0.00$ \\
Banana stem-Middle part (BS-Mid) & $0.04 \pm 0.00$ \\
Banana stem-Upper part (BS-Up) & $0.04 \pm 0.00$ \\
Total & $65.53 \pm 0.03$ \\
\hline
\end{tabular}




\subsection{Determination of the residual methane potential of the digestates}

Residual potential of the reactors' effluents was assessed to determine losses (which might cause emissions to atmosphere) of $\mathrm{CH}_{4}$ from the incomplete digestion of the influents in the fixed-dome reactors. Samples of $20 \mathrm{~mL}$ of effluent were taken from each of the three reactors under steady-state, three times per week, over a three-week period, amounting to nine samples per reactor. The samples were introduced in $118 \mathrm{ml}$ batch bottles, flashed with $\mathrm{N}_{2} / \mathrm{CO}_{2}\left(80 / 20 \% \mathrm{vv}^{-1}\right)$, closed with butyl rubber stoppers, sealed with aluminum caps and inoculated under mesophilic conditions $\left(37^{\circ} \mathrm{C}\right)$.

\subsection{Analyses}

TS, DM, VS, TKN and total $\mathrm{NH}_{3}$, were determined based on standard methods (APHA, 2005). The methane production in the both BMP assays and the residual methane potentials was measured by gas chromatography (Shimatzu gas chromatograph) with flame ionization detector (Symsaris et al., 2015). Biogas composition in the headspace of the fixed-dome reactors was measured with an 82-12 Microlab Århus A/S gas chromatographer (Flores et al., 2015). Volatile fatty acids (VFA) were measured with a Shimadzu GC-2010 gas chromatographer with a Shimadzu AOI-20i auto injector. The $\mathrm{pH}$ was determined with a digital $\mathrm{pH}$ meter (FEP20 Mettler, Toledo).

\subsection{Statistical analysis and calculations}

GraphPad Prism program (GraphPad Software, Inc., San Diego, California) was used for all statistical analysis. One-way ANOVA and the Student's t test for statistically significant difference $(p<0.05)$ were used to compare the methane production rates of the fixed-dome reactors and BMP values of the substrates, 
respectively. The co-digestion effect in the Batch assay-II was calculated based on BMP values of mono-substrate tested in BMP assay-I. The expected methane production of the fixed-dome reactor experiments was calculated based on the BMP of the monosubstrates (BMP assay-I) and compared with the obtained methane production. Methane production yield and rate of each steady-state of the fixed-dome reactors was calculated as the average methane yield and production in the steady-state period. Steady-state was defined as a ten successive operation days period, with less than $10 \%$ variation in methane yield, methane rate and $\mathrm{pH}$ (Søndergaard et al., 2015). The $\mathrm{CO}_{2}$ equivalent was calculated as $25 \mathrm{~kg} \mathrm{CO}_{2}$ equivalent $\mathrm{kg}^{-1} \mathrm{CH}_{4}$ (Stocker et al., 2013). The upper calorific value of methane was used $\left(11.04 \mathrm{kWh} \mathrm{m}^{-3} \mathrm{CH}_{4}\right)$ to evaluate the energy recovery from the three fixed-dome reactor scenarios (Schley et al., 2010).

\section{Results and Discussion}

\subsection{BMP assay-I, Mono-substrates}

Rice straw (RSt) had statistically (p<0.05) the higher BMP values (up to $364 \mathrm{NmL}$ $\mathrm{CH}_{4} \mathrm{~g}^{-1}$ VS) compared to all substrates and organic loads tested (Fig. 1) and, at the same time, similar to previous studies where RSt was also tested (e.g. (Mussoline et al., 2013)). Although, RSt is mainly composed of lignin, cellulose and hemicellulose, thus it is difficult to be catabolized, when the right inoculum (acclimatized to fibrous substrates) is used, it can give high BMP values (Quintero et al., 2012). By contrast, all the tested organic loads of banana by-products, BS-Lo, BS-Mid and wastewater (WW) had BMP values below $150 \mathrm{NmL} \mathrm{CH}_{4} \mathrm{~g}^{-1}$ VS. Especially, WW had a BMP value lower than $50 \mathrm{NmL} \mathrm{CH}_{4} \mathrm{~g}^{-1} \mathrm{VS}$, which was much lower than the typical methane potentials (>300 NmL CH $\mathrm{g}^{-1} \mathrm{VS}$ ) of municipal WWs in European countries (Koch et al., 2016). 
This BMP value could be attributed to the lack of proper collection infrastructure in the remote rural area sites that allows inorganic (VS/TS ratio 44.1\%) and indigestible organic (e.g. lignocellulosic material) into the WW. Nevertheless, WW is necessary in order to maintain the TS of the feedstock inside the favorable limits of $80-100 \mathrm{~g} \mathrm{~L}^{-1}$ (Weiland, 2006). Furthermore, despite the low BMP value, it is crucial for good hygienic conditions of these areas, WW to be treated in the AD reactors in order to reduce the potential contagious diseases such as diarrhea, cholera and tuberculosis (Lohani et al., 2013). Interestingly, BS-Up had a maximum BMP value of $186 \mathrm{NmL}$ $\mathrm{CH}_{4} \mathrm{~g}^{-1} \mathrm{VS}$ that was significantly higher than the BMPs of BS-Lo and BS-Mid. This BMP value was comparable to previous studies were was found to be $206-245 \mathrm{NmL}$ $\mathrm{CH}_{4} \mathrm{~g}^{-1}$ VS (Kalia et al., 2000).

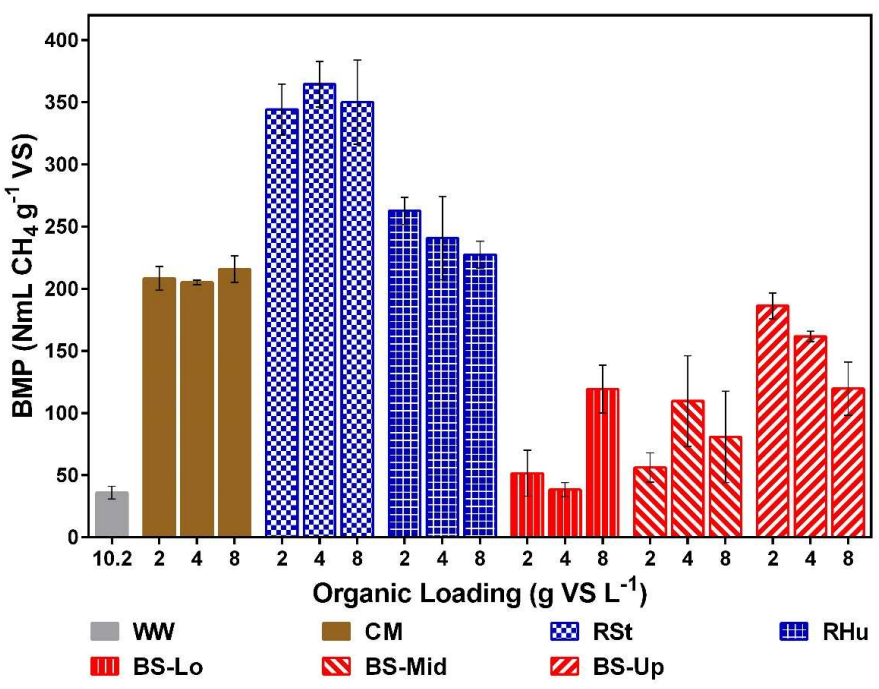

Fig. 1. Methane yield of mono-substrates under different organic loads. Wastewater (WW), cow manure (CM), banana lower, middle and upper part (BS-Lo, BS-Mid and BS Up, respectively) and rice straw and husk (RSt and RHu, respectively) 
It has been reported that rice husk is an unsuitable $\mathrm{AD}$ substrate due to low biodegradability (Li et al., 2013). Nonetheless, in the present study, RHu had statistically the second higher BMP value (250 $\left.\mathrm{NmL} \mathrm{CH}_{4} \mathrm{~g}^{-1} \mathrm{VS}\right)$ compared to all mono-substrates tested. This could be partially explained by the improvement of the very high $\mathrm{C} / \mathrm{N}$ ratio (>100) of the $\mathrm{RHu}$ (Li et al., 2013), due to the extra nitrogen derived from the manure-based inoculum, as well as, the pre-existing ability of the used inoculum to treat lignocellulosic feedstocks (Shi et al., 2013). Finally, CM had a BMP value above $200 \mathrm{NmL} \mathrm{CH}_{4} \mathrm{~g}^{-1} \mathrm{VS}$, which was inside the expected methane potential limits presented in the literature (Qiao et al., 2011).

\subsection{BMP assay-II, Co-substrates}

The two "all substrates" mixing combinations, had statistically the highest $(p<0.05)$ BMP values compared to all the co-digestion scenarios tested in BMP assay-II (Fig. 2a). Notably, between the two "all substrates" combinations tested, 6M had the highest BMP value but the $12 \mathrm{M}$ had threefold higher co-digestion effect (Fig. 2b). This means that "all substrates $12 \mathrm{M}$ " was the most efficient co-digestion scenario, which ensured both high methane yield, and optimum biomasses degradation.

Both co-digestion scenarios with "WW+CM+RHu" and "WW+CM+RSt" had similar $(p>0.05)$ BMP values but, at the same time, they had a strong negative codigestion effect with up to $-45 \%$ lower methane potential compared to the expected (Fig. 2). These results are contradicting with a previous research paper, were rice husk and straw shown a positive effect when co-digested with dairy manure (Hills and Roberts, 1981). Furthermore, the "WW+CM" co-digestion had more than $20 \%$ better BMP values compared to the expected, based on the mono-digestion results. Thus, CM and WW were not the reason for the low methane potential of the rice by-products co- 
digestions. Most probably, the high lignocellulosic content of the rice by-products alongside with the high organic load (high $\mathrm{C} / \mathrm{N}$ ratio) had caused the sub-optimal utilization of the expected methane potential.

All banana stems co-digestion combinations had similar methane yields, which were higher compared to the expected ones as calculated by the methane yields of the single substrates, indicating synergistic co-digestion effect. Oliveira et al. (2007) has reported that banana stems contain calcium and magnesium, which are beneficial nutrients for the anaerobic microbial communities (Schattauer et al., 2011). It seems that this characteristic of the banana stems was also contributed to the high methane yields of "all substrates" combination. Nevertheless, the fibrous nature of banana stems and the high water content hinders them to be the only co-digestion substrate in a manure based reactor (Kalia et al., 2000), which is in accordance with the results of this study.

In brief, all the substrates tested in BMP assay-II contributed with some benefits for the AD process (e.g. WW: TS levels regulation; CM: biomethanation microbial communities; banana stem parts: nutrients; rice by-products: high methane potential). Furthermore, the positive synergistic effect from co-digesting all the substrates $(12 \mathrm{M}$ combination) provided the best utilization scenario of the available agricultural byproducts. Thus, this co-digestion scenario was chosen to be tested in the three fixeddome continuous reactors. 

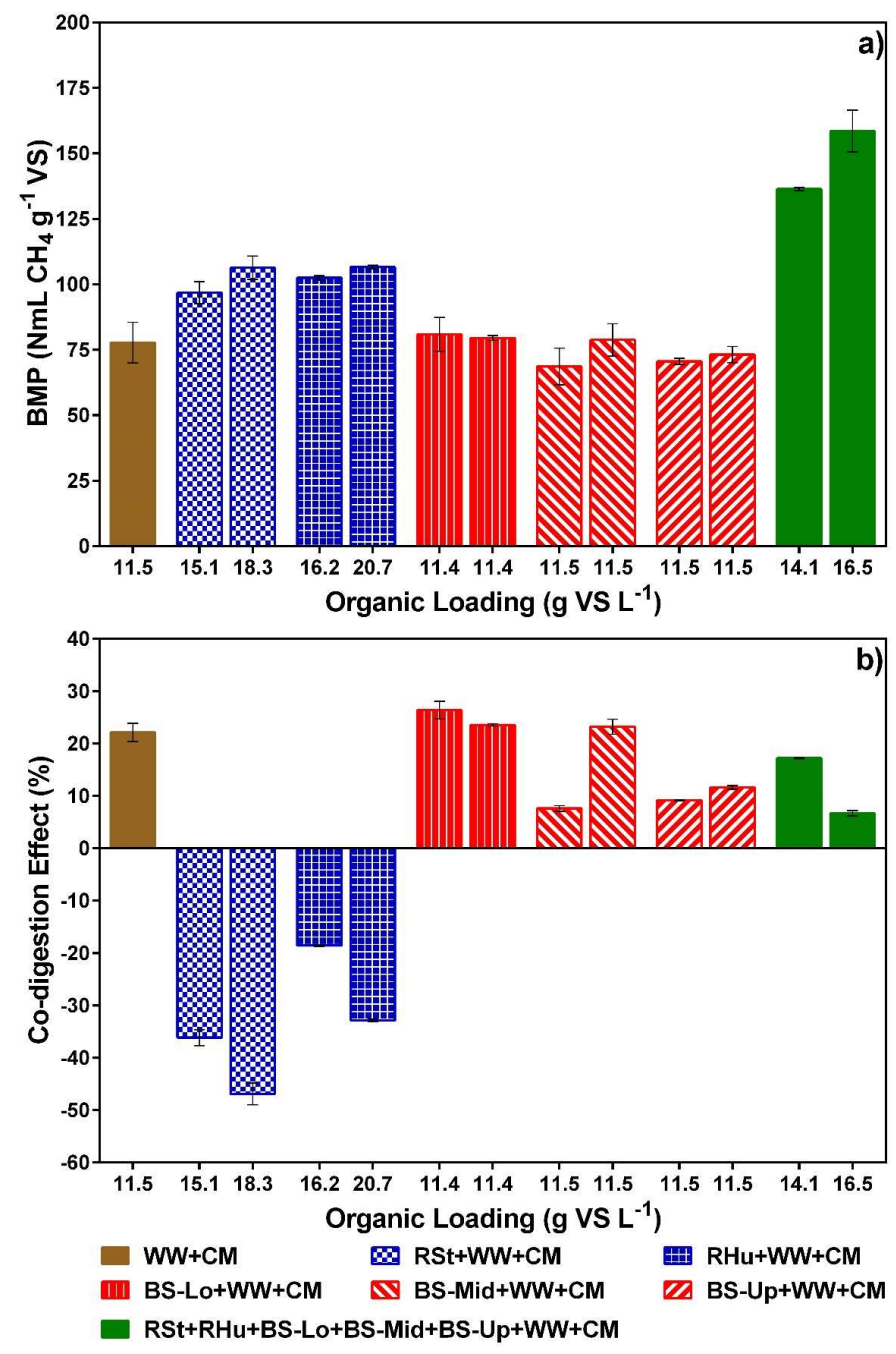

Fig. 2. The a) maximum methane yields and b) co-digestion effect compared to the maximum yields, obtained in BMP assay-I. Wastewater (WW), cow manure (CM), banana lower, middle and upper part (BS-Lo, BS-Mid and BS-Up, respectively) and rice husk and straw (RHu and $\mathrm{RSt}$, respectively)

\subsection{Fixed-dome continuous reactors}

The maximum methane yield was observed in reactor $\mathrm{R}_{60}$, with a value of $106 \mathrm{NmL}$ $\mathrm{CH}_{4} \mathrm{~g}^{-1}$ VS while reactors $\mathrm{R}_{45}$ and $\mathrm{R}_{30}$ had maximum yields of $98.4 \mathrm{NmL}$ and $66.9 \mathrm{NmL}$ $\mathrm{CH}_{4} \mathrm{~g}^{-1}$ VS, respectively (Fig. 3a). The reactors reached a steady-state 15, 14 and 19 
days after the experiments started, with average methane production yields of 58.6, 75.6 and 85.2 $\mathrm{NmL} \mathrm{CH}_{4} \mathrm{~g}^{-1} \mathrm{VS}$ for $\mathrm{R}_{30}, \mathrm{R}_{45}$ and $\mathrm{R}_{60}$, respectively. These average methane yields were significantly different between them $(p<0.05)$, clearly indicating that yields were increasing alongside with the HRT of each reactor. On the other hand, the methane production rates (Fig. 3b) of the three reactors showed an opposite tendency compared to the yields due to the different OLR of the reactors. Thus, the highest methane production rate under steady-state, was $148 \mathrm{NmL} \mathrm{CH}_{4} \mathrm{~L}^{-1} \mathrm{~d}^{-1}$ for $\mathrm{R}_{30}$, followed by $\mathrm{R}_{45}$ with $127 \mathrm{NmL} \mathrm{CH}_{4} \mathrm{~L}^{-1} \mathrm{~d}^{-1}$ and $\mathrm{R}_{60}$ with $107 \mathrm{NmL} \mathrm{CH}_{4} \mathrm{~L}^{-1} \mathrm{~d}^{-1}$. The comparison of the average yields of each reactor (under steady-state) to the maximum yield that was observed in the BMP experiments (Fig. S3, supplementary material), showed that reactors $R_{30}, R_{45}$ and $R_{60}$ had achieved 43,56 and $63 \%$, respectively, of the maximum expected yield. If it is taken into account that the BPM experiments were performed under optimal conditions (e.g. thermophilic temperature, no incubation time limit, different VS concentrations), then reactor $\mathrm{R}_{60}$ had shown a remarkable ability to efficiently digest the used substrate. Finally, throughout the experimental period, the methane content of the produced biogas was $60-64 \%$ for $\mathrm{R}_{30}, 59-67 \%$ for $\mathrm{R}_{45}$ and 61 $67 \%$ for $\mathrm{R}_{60}$. 

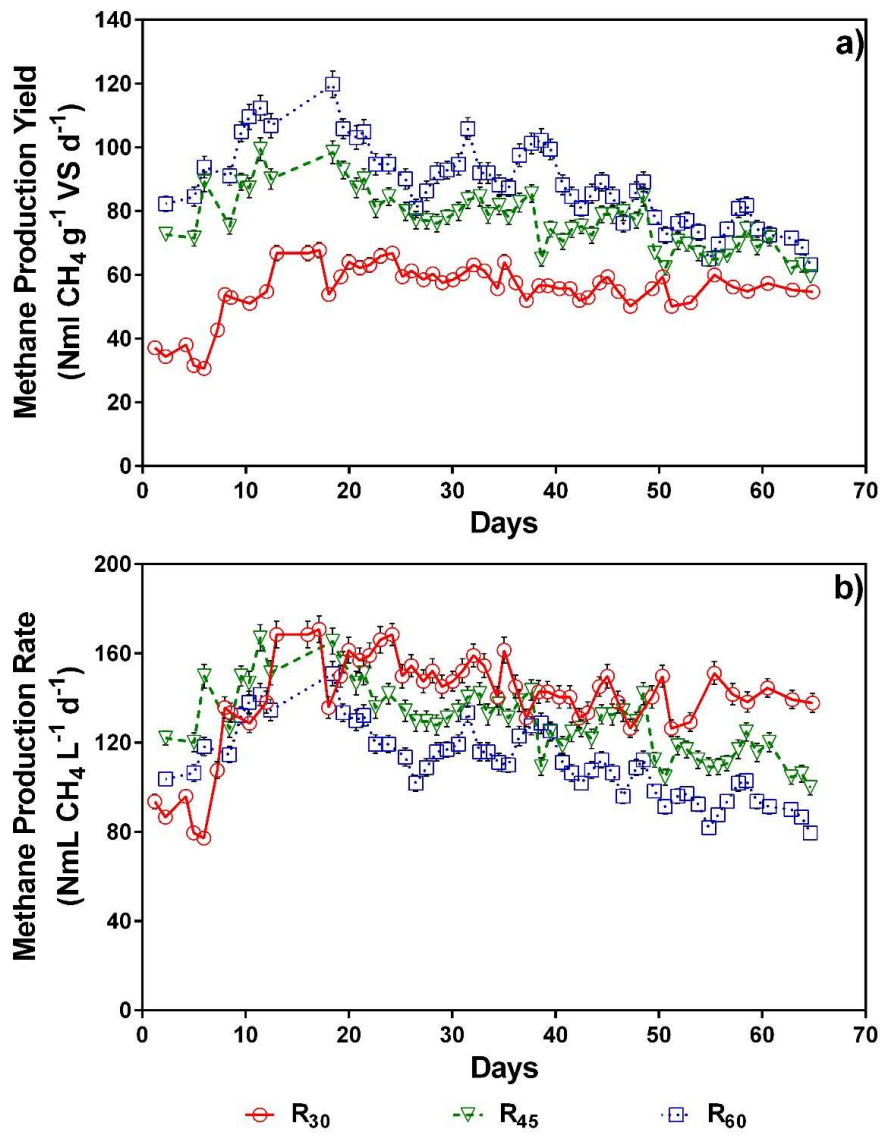

Fig. 3. The methane production a) yields and b) rates of the fixed-dome reactors

A threshold of $1500 \mathrm{mg} \mathrm{HAc}^{-1}$ of total VFA concentration is reported in the literature for a healthy continuous AD process (Søndergaard et al., 2015). Based on that, all three reactors were operating properly (Fig. 4a) however, the HRT of reactors $\mathrm{R}_{45}$ and $\mathrm{R}_{30}$ were not enough for an efficient anaerobic process and thus their methane productions yields were lower than reactor's $\mathrm{R}_{60}$. It is well know that hydrolysis is the bottleneck for AD process kinetics when lignocellulosic substrates are used (Strong et al., 2011). Therefore, it seems that the high hemicellulose and lignin content (Ibrahim et al., 2013) of the rice and banana by-products that used as substrates, had slowed down the hydrolysis step, which affected the overall kinetics of the AD process. The $\mathrm{pH}$ 
fluctuation for all reactors was between 8.2 and 8.5 in the beginning of the experiments; when the steady-states were established the $\mathrm{pH}$ values decreased and stabilized in the area of 7.8-7.9 until the end of the experiments (Fig. 4b). The VFA accumulation was not high in the reactors in order to create a $\mathrm{pH}$ drop, which is the main cause of inhibition associated with VFA. Nevertheless, the optimal range of $\mathrm{pH}$ for $\mathrm{AD}$ is from our experience 6.8-8.2, thus, $\mathrm{pH}$ levels remained, for all three reactors, inside the favorable range throughout the experiment.
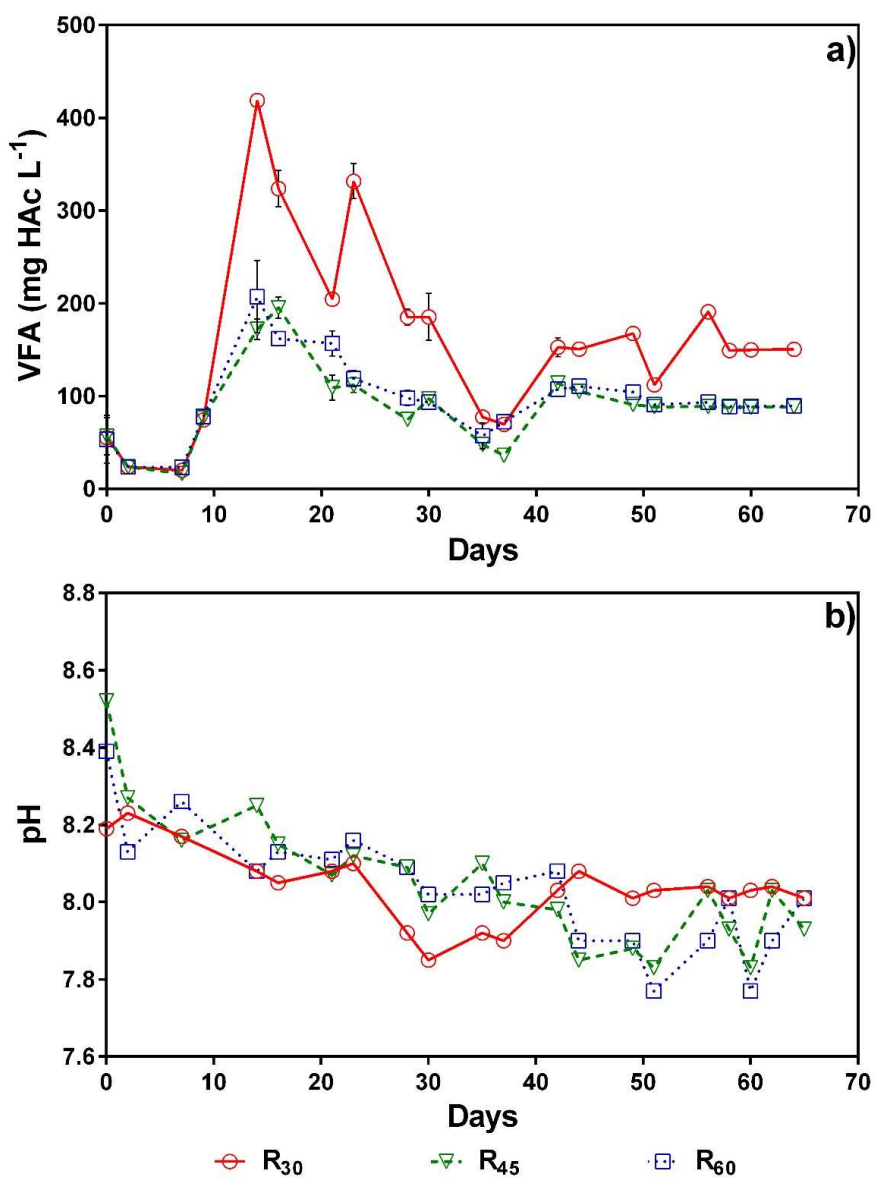

Fig. 4. The a) total VFA accumulation and b) $\mathrm{pH}$ fluctuation of the fixed-dome reactors 


\subsection{Residual methane potential, energy production and GHG emissions of}

\section{the fixed-dome reactors}

The residual methane potential of the digestates from reactors $R_{30}, R_{45}$ and $R_{60}$ were 43.5, 48.2 and $52.5 \mathrm{NmL} \mathrm{CH}_{4} \mathrm{~g}^{-1} \mathrm{VS}$, respectively (Fig. S4, supplementary material). Even though it seems that the $\mathrm{R}_{30}$ had smaller post-digestion losses per $\mathrm{g} V \mathrm{~V}$, since the reactors were operating under different OLRs, the methane emissions per working volume of the reactors were 94.8, 70.4 and 57.2 $\mathrm{NmL} \mathrm{CH}_{4} \mathrm{~L}^{-1}$ for $\mathrm{R}_{30}, \mathrm{R}_{45}$ and $\mathrm{R}_{60}$, respectively. These residual methane potential of the effluents was amounting to up to $44 \%$ methane production compared to the productions of the main reactors (Fig. 5). Residual potentials have been reported to be from $5 \%$ up to $45 \%$ of the total methane potential of optimally operated reactors, depending on the incubation period (30 to more than 100 days), the temperature $\left(5-55^{\circ} \mathrm{C}\right)$ and the source of the mono-or co-substrates (manures, agricultural and industrial by products etc.) (Kaparaju and Rintala, 2005; Kaparaju and Rintala, 2003; Weiland, 2003), Moreover, investigation of Danish centralized biogas plants, had shown losses from $5 \%$ to up to $25 \%$, depending on the hydraulic retention time (Angelidaki et al., 2005). These previous results are coinciding with our current investigation. Therefore, based both on the continuous and residual methanation experiments, $\mathrm{R}_{60}$ reactor scenario could provide $45 \%$ and $13 \%$ more energy than the $\mathrm{R}_{30}$ and $\mathrm{R}_{45}$ fixed-dome reactor scenarios, respectively for the same quantity of the available agricultural by-products (Table 4). Practically, for the rural area site assessed in the current study, the utilization of the identified agricultural by-products with the $\mathrm{R}_{60}$ reactor scenario could provide enough energy to cover completely all the daily cooking requirements of the inhabitants (Table S2, supplementary material). At the same time, the $\mathrm{GHG}$ emissions $\left(\mathrm{CO}_{2}\right.$ equivalent) per working volume reactor (based 
only on the residual methane potential) were $69 \%$ and $25 \%$ lower for $\mathrm{R}_{60}$, compared to $\mathrm{R}_{30}$ and $\mathrm{R}_{45}$ reactors, respectively. However, it was out of the scope of this study to assess meticulously the overall GHG and other emissions derived from the fixed-dome reactors and compare it with the conventional disposal methods of the used agricultural by-products. Additionally, in order to validate all the technical, social and economic parameters involved, full-scale experimental assessment has to be performed. With this in mind, a fixed-dome reactor operating with 60 days HRT, fed with all the available substrates (yearly produced quantities proportionally introduced in the feedstock), was the best co-digestion scenario for the representative remote rural area, both in terms of energy recovery and in terms of GHG emissions' reduction. This result indicates that even in the most remote rural areas, is possible to operate efficiently low-tech biogas reactors and, is the lack of knowledge dissemination to the reactor operators, which forces some of them to shut down their reactors.

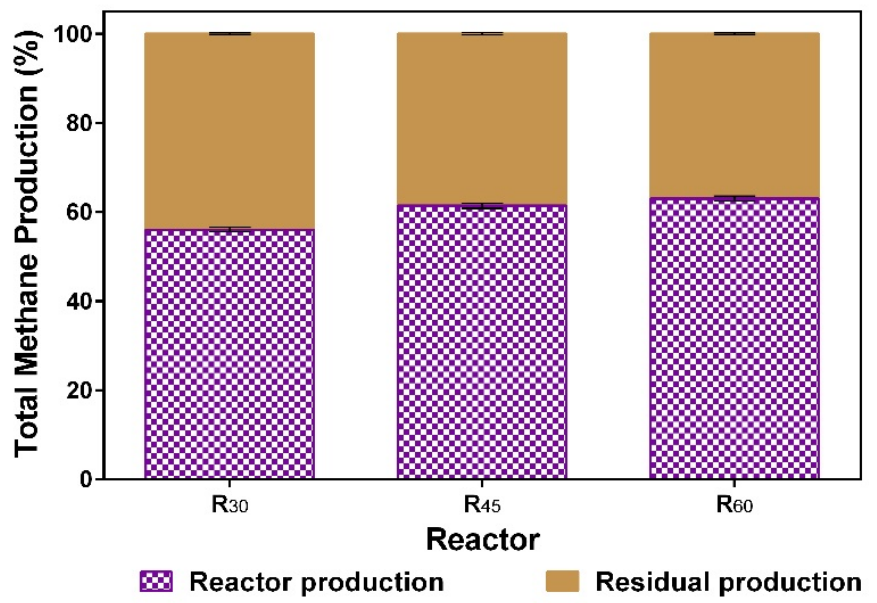

Fig. 5. The residual methane production of the digestates compared to their methane production yields of the three fixed-dome reactors under steady-state 
Table 4. Potential methane production, energy production and GHG emissions for each one of the three fixed-dome reactors co-digestion scenarios

\begin{tabular}{lccc}
\hline & $\mathrm{R}_{30}$ & $\mathrm{R}_{45}$ & $\mathrm{R}_{60}$ \\
\hline Expected methane production $\left(\mathrm{Nm}^{3} \mathrm{tn}^{-1} \mathrm{VS}\right)$ & 58.6 & 75.6 & 85.2 \\
Upper calorific value $\left(\mathrm{kWh} \mathrm{tn}{ }^{-1} \mathrm{VS}\right)$ & 646.9 & 834.6 & 940.6 \\
$\mathrm{CO}_{2}$ Equivalent $\left(\mathrm{kg} \mathrm{CO}\right.$ Eq. $\mathrm{m}^{-3}$ reactor) & 1.7 & 1.3 & 1.0 \\
\hline
\end{tabular}

\section{Conclusions}

The focus of the present work was to identify available AD substrates in a remote rural area site and to propose a continuous anaerobic co-digestion scenario, established in lab-scale, fixed-dome reactors, in order to utilize optimally these substrates. The results have established that rice husk, straw and banana stems could potentially be favorable biomethanation co-substrates. Additionally, a reactor operating with 60 days HRT and fed proportionally (based on the yearly availability) with all the by-products, was the best co-digestion scenario. Specifically, this scenario showed high-energy recovery (up to 45\%) from the substrates and lower post-methanation GHG emissions (up to $69 \%$ ), compared to the other scenarios tested. Thus, this study has clearly shown that, when the proper biomethanation scenario is applied in fixed-dome reactors, highenergy production together with low environmental impact can be achieved. This knowledge could potentially motivate the inhabitants of remote rural areas, where lowtech reactors have been abandoned, to reconsider their decision.

\section{Acknowledgements}


This work was supported by European Community's FP7 under the project "Energy-efficient, community-based water and wastewater-treatment systems for deployment in India-ECO-India” (grant agreement number: 308467). The authors would like to thank Asger S. Andersen, Leifur B. Erlendsson, Sofie K. Schultz and Mads A. Sørensen for their contribution to the preliminary characterization of the agricultural byproducts.

\section{References}

Alburquerque, J.A., de la Fuente, C., Campoy, M., Carrasco, L., Nájera, I., Baixauli, C., Caravaca, F., Roldán, A., Cegarra, J., Bernal, M.P., 2012. Agricultural use of digestate for horticultural crop production and improvement of soil properties. Eur. J. Agron. 43, 119-128.

Angelidaki, I., Alves, M., Bolzonella, D., Borzacconi, L., Campos, J., Guwy, A., Kalyuzhnyi, S., Jenicek, P., Van Lier, J., 2009. Defining the biomethane potential (BMP) of solid organic wastes and energy crops: a proposed protocol for batch assays. Water Sci. Technol. 59, 927-934.

Angelidaki, I., Boe, K., Ellegaard, L., 2005. Effect of operating conditions and reactor configuration on efficiency of full-scale biogas plants. Water Sci. Technol. 52, 189-194.

APHA, 2005. Standard methods for the examination of water and wastewater, $21^{\text {th }}$ ed. American Public Health Association, Washington, DC.

Banerjee, M., Prasad, R., Rehman, I.H., Gill, B., 2016. Induction stoves as an option for clean cooking in rural India. Energy Policy 88, 159-167. 
Bohra, S., Dey, K.P., Kundu, D., Naskar, M.K., 2013. Synthesis of zeolite T powders by direct dissolution of rice husk ash: an agro-waste material. J. Mater. Sci. 48, 78937901.

Bond, T., Templeton, M.R., 2011. History and future of domestic biogas plants in the developing world. Energy Sustain Dev. 15, 347-354.

Chang, I.S., Zhao, J., Yin, X., Wu, J., Jia, Z., Wang, L., 2011. Comprehensive utilizations of biogas in Inner Mongolia, China. Renewable Sustainable Energy Rev. 15, 1442-1453.

Cheng, S., Li, Z., Mang, H.-P., Neupane, K., Wauthelet, M., Huba, E.-M., 2014. Application of fault tree approach for technical assessment of small-sized biogas systems in Nepal. Appl. Energy 113, 1372-1381.

Cozzi, L., 2011. World Energy Outlook 2011, in: van der Hoeven, M. (Ed.). International Energy Agency, Paris, France.

Dedinec, A., Markovska, N., Ristovski, I., Velevski, G., Gjorgjievska, V.T., Grncarovska, T.O., Zdraveva, P., 2015. Economic and environmental evaluation of climate change mitigation measures in the waste sector of developing countries. J. Cleaner Prod. 88, 234-241.

Flores, G.A.E., Fotidis, I.A., Karakashev, D.B., Kjellberg, K., Angelidaki, I., 2015. Effects of Benzalkonium Chloride, Proxel LV, P3 Hypochloran, Triton X-100 and DOWFAX 63N10 on anaerobic digestion processes. Bioresour. Technol. 193, 393-400.

Hills, D.J., Roberts, D.W., 1981. Anaerobic digestion of dairy manure and field crop residues. Agric. Wastes 3, 179-189. 
Ibrahim, M., El-Zawawy, W., Jüttke, Y., Koschella, A., Heinze, T., 2013. Cellulose and microcrystalline cellulose from rice straw and banana plant waste: preparation and characterization. Cellulose 20, 2403-2416.

IEA, 2011. Energy For All. Financing Access for the Poor. Special Early Excerpt of the World Energy Outlook 2011. First presented at the Energy For All Conference, Oslo, Norway, October 2011. International Energy Agency, OECD-IEA: Paris.

IEA, 2013. World Energy Outlook 2013, Executive Summary. International Energy Agency.

Jha, A.K., Li, J., Ban, Q., Zhang, L., Zhao, B., 2012. Dry anaerobic digestion of cow dung for methane production: Effect of mixing. Pak. J. Biol. Sci. 15, 1111.

Kalia, V.C., Sonakya, V., Raizada, N., 2000. Anaerobic digestion of banana stem waste. Bioresour. Technol. 73, 191-193.

Kaparaju, P., Rintala, J., 2005. Anaerobic co-digestion of potato tuber and its industrial by-products with pig manure. Resour. Conserv. Recycl. 43, 175-188.

Kaparaju, P.L.N., Rintala, J.A., 2003. Effects of temperature on post-methanation of digested dairy cow manure in a farm-scale biogas production system. Environ. Technol. 24, 1315-1321.

Koch, K., Plabst, M., Schmidt, A., Helmreich, B., Drewes, J.E., 2016. Co-digestion of food waste in a municipal wastewater treatment plant: Comparison of batch tests and full-scale experiences. Waste Management 47, Part A, 28-33.

Li, Y., Zhang, R., Liu, G., Chen, C., He, Y., Liu, X., 2013. Comparison of methane production potential, biodegradability, and kinetics of different organic substrates. Bioresour. Technol. 149, 565-569. 
Lohani, S., Chhetri, A., Adhikari, J., Bakke, R., 2013. Sustainable Biogas Production Potential from Urban Wastewater in Nepal. Int. J. Environ. Sci. Dev. 4, 595-599.

Mussoline, W., Esposito, G., Lens, P., Spagni, A., Giordano, A., 2013. Enhanced methane production from rice straw co-digested with anaerobic sludge from pulp and paper mill treatment process. Bioresour. Technol. 148, 135-143.

Mwirigi, J., Balana, B.B., Mugisha, J., Walekhwa, P., Melamu, R., Nakami, S., Makenzi, P., 2014. Socio-economic hurdles to widespread adoption of small-scale biogas digesters in Sub-Saharan Africa: A review. Biomass Bioenergy 70, 17-25.

Oliveira, L., Cordeiro, N., Evtuguin, D., Torres, I., Silvestre, A., 2007. Chemical composition of different morphological parts from 'Dwarf Cavendish'banana plant and their potential as a non-wood renewable source of natural products. Ind. Crops Prod. 26, 163-172.

Pérez, I., Garfí, M., Cadena, E., Ferrer, I., 2014. Technical, economic and environmental assessment of household biogas digesters for rural communities. Renewable Energy 62, 313-318.

Pode, R., 2016. Potential applications of rice husk ash waste from rice husk biomass power plant. Renewable Sustainable Energy Rev. 53, 1468-1485.

Purohit, P., 2009. Economic potential of biomass gasification projects under clean development mechanism in India. J. Cleaner Prod. 17, 181-193.

Qiao, W., Yan, X., Ye, J., Sun, Y., Wang, W., Zhang, Z., 2011. Evaluation of biogas production from different biomass wastes with/without hydrothermal pretreatment. Renewable Energy 36, 3313-3318. 
Quintero, M., Castro, L., Ortiz, C., Guzmán, C., Escalante, H., 2012. Enhancement of starting up anaerobic digestion of lignocellulosic substrate: fique's bagasse as an example. Bioresour. Technol. 108, 8-13.

Rao, P.V., Baral, S.S., Dey, R., Mutnuri, S., 2010. Biogas generation potential by anaerobic digestion for sustainable energy development in India. Renewable Sustainable Energy Rev. 14, 2086-2094.

Roubík, H., Mazancová, J., Banout, J., Verner, V., 2016. Addressing problems at smallscale biogas plants: a case study from central Vietnam. J. Cleaner Prod. 112, Part 4, 2784-2792.

Schattauer, A., Abdoun, E., Weiland, P., Plöchl, M., Heiermann, M., 2011. Abundance of trace elements in demonstration biogas plants. Biosystems Eng. 108, 57-65.

Schley, P., Beck, M., Uhrig, M., Sarge, S., Rauch, J., Haloua, F., Filtz, J.-R., Hay, B., Yakoubi, M., Escande, J., 2010. Measurements of the calorific value of methane with the new GERG reference calorimeter. Int. J. Thermophys. 31, 665-679.

Seppälä, M., Pyykkönen, V., Väisänen, A., Rintala, J., 2013. Biomethane production from maize and liquid cow manure - Effect of share of maize, post-methanation potential and digestate characteristics. Fuel 107, 209-216.

Shi, J., Wang, Z., Stiverson, J.A., Yu, Z., Li, Y., 2013. Reactor performance and microbial community dynamics during solid-state anaerobic digestion of corn stover at mesophilic and thermophilic conditions. Bioresour. Technol. 136, 574581.

Singh, K.J., Sooch, S.S., 2004. Comparative study of economics of different models of family size biogas plants for state of Punjab, India. Energy Convers. Manage. 45, $1329-1341$. 
Søndergaard, M.M., Fotidis, I.A., Kovalovszki, A., Angelidaki, I., 2015. Anaerobic codigestion of agricultural by-products with manure, for enhanced biogas production. Energy Fuels, "in press".

Sovacool, B.K., Kryman, M., Smith, T., 2015. Scaling and commercializing mobile biogas systems in Kenya: A qualitative pilot study. Renewable Energy 76, 115125.

Stocker, T., Qin, D., Plattner, G., Tignor, M., Allen, S., Boschung, J., Nauels, A., Xia, Y., Bex, B., Midgley, B., 2013. IPCC, 2013: climate change 2013: the physical science basis. Contribution of working group I to the fifth assessment report of the intergovernmental panel on climate change.

Strong, P.J., McDonald, B., Gapes, D.J., 2011. Combined thermochemical and fermentative destruction of municipal biosolids: A comparison between thermal hydrolysis and wet oxidative pre-treatment. Bioresour. Technol. 102, 5520-5527.

Suzuki, M., 2015. Identifying roles of international institutions in clean energy technology innovation and diffusion in the developing countries: matching barriers with roles of the institutions. J. Cleaner Prod. 98, 229-240.

Symsaris, E.C., Fotidis, I.A., Stasinakis, A.S., Angelidaki, I., 2015. Effects of triclosan, diclofenac, and nonylphenol on mesophilic and thermophilic methanogenic activity and on the methanogenic communities. J. Hazard. Mater. 291, 45-51.

Thien Thu, C.T., Cuong, P.H., Hang, L.T., Chao, N.V., Anh, L.X., Trach, N.X., Sommer, S.G., 2012. Manure management practices on biogas and non-biogas pig farms in developing countries - using livestock farms in Vietnam as an example. J. Cleaner Prod. 27, 64-71. 
Tilley, E., Ulrich, L., Lüthi, C., Reymond, P., Zurbrügg, C., 2014. Compendium of sanitation systems and technologies. Swiss Federal Institute of Aquatic Science and Technology (Eawag), Dübendorf, Switzerland.

Ullah, K., Kumar Sharma, V., Dhingra, S., Braccio, G., Ahmad, M., Sofia, S., 2015. Assessing the lignocellulosic biomass resources potential in developing countries: A critical review. Renewable Sustainable Energy Rev. 51, 682-698.

Weiland, P., 2003. Production and energetic use of biogas from energy crops and wastes in Germany. Appl. Biochem. Biotechnol. 109, 263-274.

Weiland, P., 2006. Biomass digestion in agriculture: A successful pathway for the energy production and waste treatment in Germany. Eng. Life Sci. 6, 302-309. 


\section{Highlights}

- Wastewater in remote rural areas could have extremely low $\mathrm{CH}_{4}$ potential

- Rice husks demonstrated a high biomethanation potential of $250 \mathrm{NmL} \mathrm{CH}_{4} \mathrm{~g}^{-1} \mathrm{VS}$

- Banana stems used as co-substrate enhanced AD efficiency up to $25 \%$

- Longer HRTs in fixed-dome reactors lead to higher $\mathrm{CH}_{4}$ and lower $\mathrm{GHG}$ productions

- $\mathrm{AD}$ of unused by-products can cover $100 \%$ of the cooking needs in a remote rural area 